Stawomir Zatwardnicki Papieski Wydział Teologiczny we Wroctawiu

\title{
Niepokalane Poczęcie. Czy łaska Odkupienia działa wstecz?
}

\section{THE IMMACULATE CONCEPTION. DOES THE GRACE OF REDEMPTION WORK BACKWARDS?}

Marian dogmas are often being criticised. In case of the Immaculate Conception the following question is asked: how had been the redemption possible before Christ redeemed people? It is worthwhile to meditate the contents hidden in this Marian dogma, for the Mother of God's unique vocation gives light to all the people's vocation. The Immaculate Conception reveals the following truths: relation between the eternal will of God (predestination) and the will of man (freedom); relation between the divine grace and human cooperation; connection between temporality and eternity.

Key words: God, man, Christ, Incarnation, Mary, Mother of God, the Immaculate Conception, will, time, eternity, history, predestination, freedom, grace, cooperation, redemption, vocation.

\section{Wstęp: trudności z przyjęciem uprzedniego Odkupienia}

Ze strony niekatolickich chrześcijan formułowana bywa krytyka katolickich dogmatów maryjnych. Ostrze krytycznych opinii kieruje się często przeciw Niepokalanemu Poczęciu, które wydaje się przeczyć wynikającej z Pisma Świętego powszechności grzechu, któremu 
podlegają wszyscy ${ }^{1}$. Z kolei tłumaczenia katolików, że nie czynią wyjątku od reguły, ale stwierdzeniem dogmatycznym dają do zrozumienia, że również Maryja potrzebowała Odkupienia ${ }^{2}$, tyle że dokonało się ono w sposób uprzedni (mocą przewidzianych zasług Zbawiciela i szczególnej łaski) ${ }^{3}$, prowadzi często do podnoszenia kwestii, czy w ogóle możliwe jest Odkupienie, zanim Chrystus dokonał odkupieńczego dzieła. Na ile wolno mi wyciągać wnioski na podstawie własnego doświadczenia w kontaktach z katolikami oraz przeprowadzonych na

1 Por. S. C. Napiórkowski, Spór o Matkę Pana. Mariologia jako problem ekumeniczny (Teologia w dialogu, 12), Lublin 2011, s. 55: „Chociaż Luter przyjmował niepokalane poczęcie, współczesne kierunki protestantyzmu powszechnie odrzucają naukę o wolności Maryi od grzechu pierworodnego". Por. również: Cz. Bartnik, Matka Boża (Biblioteka Katedry Teologii Historycznej, 1), Lublin 2012, s. 130 [dalej cyt. BMB]: „Marcin Luter na początku przyjmował bezgrzeszność Maryi, później uczył, że podlegała Ona na równi z innymi powszechnemu prawu grzechu, a wreszcie doszedł do swojej znanej tezy dialektycznej: simul iusta et peccatrix, czyli święta i zarazem grzesznica”.

$2 \quad$ Warto przy okazji zauważyć, że tym ostrzejsza krytyka dogmatu, im bardziej Niepokalane Poczęcie zostaje zawężone do Odkupienia od grzechu pierworodnego. Tak jakby człowiek potrzebował miłosierdzia Boga jedynie w celu usprawiedliwienia, a nie przede wszystkim do prowadzenia życia w jedności z Bogiem! Por. J.M. Lipniak, Pierwsza wśród usprawiedliwionych. Reinterpretacja dogmatu o Najświętszej Maryi Panny w świetle „Wspólnej deklaracji w sprawie nauki ousprawiedliwieniu”(Rozprawy naukowe,90), red. serii: W. Irek, Wrocław 2012, s. 189 [dalej cyt. PWU]: „Związek Niepokalanego Poczęcia i Bożego miłosierdzia wyrażony jest w fakcie, iż człowiek odkupiony to człowiek, który dostąpił miłosierdzia Bożego w sposób wznioślejszy". Na pozytywny aspekt Niepokalanego Poczęcia zwracają uwagę Ojcowie Soborowi - por. Sobór Watykański II, Konstytucja dogmatyczna o Kościele „Lumen gentium”, nr 53: „Odkupiona w sposób wznioślejszy ze względu na zasługi swego Syna i zjednoczona z Nim ścisłym i nierozerwalnym węzłem, jest obdarzona tym największym darem i najwyższą godnością, która wynika z tego, że jest rodzicielką Syna Bożego i dlatego najbardziej umiłowaną córką Ojca i przybytkiem Ducha Świętego". Korzystam z wydania: Sobór Watykański II, Konstytucja dogmatyczna o Kościele „Lumen gentium”, [w:] Sobór Watykański II, Konstytucje, dekrety, deklaracje. Tekst polski. Nowe ttumaczenie, Poznań 2002, s. 104-166 [dalej cyt. LG].

Por. definicję Niepokalanego Poczęcia w: Bulla papieża Piusa IX „Ineffabilis Deus", 8 grudnia 1854 r., [w:] I. Bokwa (red.),Breviarium fidei. Wybór doktrynalnych wypowiedzi Kościoła, opr. I. Bokwa [i in.], Poznań 2007, nr 527: „Na chwałę świętej i niepodzielnej Trójcy, na cześć i uwielbienie Bożej Rodzicielki, dla wywyższenia wiary katolickiej i rozkrzewienia religii chrześcijańskiej, powagą naszego Pana Jezusa Chrystusa, świętych Apostołów Piotra i Pawła oraz Naszą ogłaszamy, orzekamy i określamy, że nauka, która utrzymuje, iż Najświętsza Maryja Panna od pierwszej chwili swego poczęcia - mocą szczególnej łaski i przywileju wszechmocnego Boga, mocą przewidzianych zasług Jezusa Chrystusa, Zbawiciela rodzaju ludzkiego - została zachowana jako nietknięta od wszelkiej zmazy grzechu pierworodnego, jest prawdą przez Boga objawioną i dlatego wszyscy wierni powinni w nią wytrwale i bez wahania wierzyé". 
niereprezentatywnej próbie wywiadów, które poprzedziły napisanie przeze mnie książki Pomoc przeciw nieprzyjaciołom Twoim ${ }^{4}$, na tyle muszę przyjąć, że podobne pytania nurtują również katolików, także tych pełniących odpowiedzialne funkcje we wspólnotach kościelnych.

Wydaje się, że kwestia, która skrywa się za trudnościami z przyjęciem „odkupienia przed odkupieniem”, pokutuje również w teologii i jest, według zdania Josepha Ratzingera wyrażonego dokładnie pół wieku temu (w Adwent 1964 r.), ale wciąż aktualnego ${ }^{5}$, jedną z kluczowych spraw, z którymi należy się uporać. Chodzi o dzielenie ludzkich dziejów na dwa okresy, przed i po Chrystusie, z czego w sposób nieunikniony wynika również segregacja ludzi na tych odkupionych oraz nieodkupionych (ci, którym przyszło żyć przed przyjściem Zbawiciela na świat, albo ci, którzy żyją „po Chrystusie”, ale nie dane im było usłyszeć Dobrej Nowiny). Taka świadomość „pękniętej” historii (i w konsekwencji również świata na ten, który słyszał o Chrystusie i pozostałą część nieznającą Ewangelii) wydaje się dziś wciąż dominować, i właśnie na tak położonym „,innym” fundamencie (1 Kor 3,11$)$ wielu buduje swoje rozumienie Odkupienia.

Z kolei z zarysowanego w tytule problemu wyłania się jeszcze jedna kwestia: jeśli jest możliwe Odkupienie „uprzednie”, to czy nie oznacza ono siłą narzuconej człowiekowi łaski? Odpowiedź na to pytanie wymaga postawienia kwestii relacji pomiędzy wolą Boga a człowieka; jak w takim razie mają się do siebie: odwieczny Boży plan Zbawienia każdego człowieka do wolnej woli ludzkiej? Narzuca się bowiem siłą rzeczy wybór pomiędzy predestynacją oraz wolną wolą; wydaje się, że nie sposób przyjąć jednego i drugiego.

Pytania te zbiegają się i niejako wzmagają właśnie w maryjnym dogmacie, co nie powinno dziwić, jeśli uwzględni się, że właśnie mariologia, jak to obrazowo przedstawił John Macquarrie, anglikański profesor teologii i prawa z Oksfordu, stanowi „miejsce spotkania dla wielkiej

$4 \quad$ S. Zatwardnicki, Pomoc przeciw nieprzyjaciołom Twoim, czyli jak chwalić Maryję i bronić Jej godności, Kraków 2014. Przy pisaniu tego artykułu rozwinąłem przemyślenia zawarte we wzmiankowanej pozycji.

$5 \quad$ Świadczy o tym choćby wciąż podnoszony przez teologów problem Zbawienia w innych religiach, którego nie da się rozwiązać bez uwzględnienia kwestii, na którą zwrócił uwagę Ratzinger. Nie tylko w teologii, ale również w duszpasterstwie kwestia ta daje o sobie znać wciąż na nowo. Dla przykładu: Nicky Gumbel, duchowny anglikański, który propaguje po całym świecie ewangelizacyjne kursy Alfa, na podstawie doświadczenia w ich prowadzeniu uznaje kwestię innych religii za jedną z najczęściej poruszanych zagadnień podnoszonych względem chrześcijaństwa - por. N. Gumbel, Co nas nurtuje. Siedem powszechnie wysuwanych zastrzė̇eń pod adresem chrześcijaństwa, tłum. R. Pruszkowski, Warszawa 1998 , s. 4. 
liczby prawd chrześcijańskich niczym węzłowa stacja w brytyjskim systemie kolejowym, gdzie spotyka się wielka liczba linii, połączeń

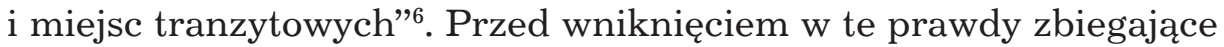
się w doktrynie maryjnej warto zauważyć, że Matka Boża, zgodnie z pozornie paradoksalnym soborowym stwierdzeniem, „w Kościele świętym zajmuje miejsca najwyższe po Chrystusie i nam najbliższe"7. Jest zatem z jednej strony powołana wyjątkowo, ale w pewnym sensie ten wyjątek jest wyjątkiem od reguły obowiązującej wszystkich wierzących $^{8}$. W Jej szczególnym powołaniu, którego jednym z wyrazów jest przywilej Niepokalanego Poczęcia, da się odczytać prawdę o powołaniu każdego chrześcijanina9 ${ }^{9}$.

\section{Tajemnica odwiecznego Bożego planu Odkupienia}

\section{Pęknięcie ludzkiej historii?}

Według Josepha Ratzingera genezy problematycznego zagadnienia, jakim jest swoiste „pęknięcie” ludzkiej historii na dwa okresy oraz „segregacja” ludzi na dwie części, które jakoby wynikają z pojęcia Odkupienia, należy szukać aż w XII wieku u Joachima de Fiore. Ten cysterski teolog dokonał zwrotu w rozumieniu teologii dziejów, dzieląc je na trzy okresy. Mimo że jego doktryna została przez Kościół odrzucona, to jednak, jak zauważa bawarski teolog:

6

W. Życiński, Mariologia Kościoła anglikańskiego, [w:] Teksty o Matce Bożej. Chrześcijaństwo ewangelickie (Beatam Me Dicent..., 10), tłum. E. Adamiak i in., red. serii: S. C. Napiórkowski, Niepokalanów 2000, s. 110.

7

Por. LG 54.

Przy okazji trzeba zwrócić uwagę na to, że krytycy dogmatu o podnoszą zarzut, jakoby ten przywilej sprawiał, że Maryja nie podlegałaby już solidarności z ludźmi, a stawałaby niejako po stronie Boga, tak że granica pomiędzy Stwórcą a stworzeniem zostałaby zatarta (por. S.C. Napiórkowski, Spóro Matkę Pana, op. cit., s. 55-56). Na ile się orientuję, również niektórzy katolicy lękają się wyjątkowości Maryi, która wydaje im się koniecznie prowadzić do tego, że wyniesiona ponad innych Maryja musi stracić kontakt ze „zwykłymi” chrześcijanami.

Według św. Maksymiliana Kolbe, który odwoływał się do jednego z objawień, w czasie którego Maryja przedstawiła się „Jestem Niepokalane Poczęcie”, w nazwie Niepokalane Poczęcie mieści się „,wiele więcej tajemnic, które z czasem odkrywane będą. Wskazuje ona bowiem, że jakoby do istoty Niepokalanej należało Jej Niepokalane Poczęcie" (M.M. Kolbe, Pisma. Cz. II, przyg. do druku P. Sotowski, Niepokalanów 2008, s. 699). Tę słuszną intuicję warto rozciągnąć na treść dogmatycznego sformułowanie - otóż w dogmacie skrywają się prawdy zbawcze, które wymagają odkrywania, mają bowiem niebagatelne znaczenie dla życia wierzących. 
przejęto od niego rozumienie wydarzenia Chrystusa jako punktu odniesienia, który mieści się wewnątrz samej historii. Zmiana ogólnego rozumienia tego, co chrześcijańskie, która stąd wynikła, jest jednym z najbardziej istotnych zwrotów w całych dziejach świadomości chrześcijańskiej. Jego przezwyciężenie stanowi jedno z najpilniejszych zadań teologii w naszych czasach $^{10}$.

Przepaści dzielącej ludzką historię na dwa okresy nie znali ani Ojcowie Kościoła, ani całe pierwsze tysiąclecie chrześcijaństwa - dowodził w swojej rozprawie habilitacyjnej ${ }^{11}$ młody Ratzinger. Mówiono o pełni czasu, a nie o zwrocie w czasie czy centrum czasów. Dla wszystkich ludzi wszystkich czasów i miejsc Chrystus jest sensem i celem, można powiedzieć, że jest przeszłością i zarazem przyszłością; również po Chrystusie żyjemy w nieustannym Adwencie, ,granica pomiędzy czasem «przed Chrystusem» i czasem «po Chrystusie» nie przebiega na zewnątrz i nie można jej narysować na mapie; biegnie ona bowiem przez nasze serce"12. Śmierci krzyżowej Chrystusa towarzyszyło - jak zanotował Ewangelista - rozdarcie zasłony przybytku, trzęsienie ziemi i pękanie skał, a nawet otwarcie grobów tych, którzy umarli przed Chrystusem. Jednak to „trzęsienie ziemi towarzyszące ukrzyżowaniu nie dzieli ziemi i czasów, ale ludzkie serca"13, jak o tym świadczy przykład setnika i jego ludzi (Mt 27,51-54).

\section{Boski plan Zbawienia}

Kościół w uroczystość Niepokalanego Poczęcia Najświętszej Maryi Panny poddaje pod uwagę fragment z Listu do Efezjan (1,3-6.11-12) mówiący o tajemniczym planie Zbawienia; warto przeczytać ten tekst w całości (od w. 3 do 14). Okazuje się, że Bóg Ojciec napełnił wierzących „wszelkim błogosławieństwem duchowym na wyżynach niebieskich w Chrystusie” (w. 3) ${ }^{14}$, w którym „wybrał nas przed założeniem świata, abyśmy byli święci i nieskalani” (w. 4). Z miłości i według powziętego

10 J. Ratzinger, O sensie bycia chrześcijaninem, tłum. J. Merecki, Kraków 2006, s. 35 , przypis 1 .

11 Polskie wydanie: J. Ratzinger, Świętego Bonawentury teologia historii, tłum. E. I. Zieliński, Lublin 2010.

12 J. Ratzinger, O sensie bycia chrześcijaninem, op. cit., s. 39.

13 S. Zatwardnicki, Ateizm urojony. Chrześcijańska odpowiedź na negację Boga, Kraków 2013, s. 196.

14 Tam, gdzie nie zaznaczono inaczej, wszystkie biblijne cytaty za: Biblia Tysiaclecia: Pismo Święte Starego i Nowego Testamentu w przektadzie z języków oryginalnych. Opracowat Zespót Biblistów Polskich z inicjatywy benedyktynów tynieckich, wyd. 5, Poznań 2003. 
postanowienia (wola Boża) ,przeznaczył nas dla siebie jako przybranych synów przez Jezusa Chrystusa" (w. 5) ${ }^{15}$, a wszystko to dokonuje się ku chwale majestatu Jego łaski, którą obdarzył nas w swoim Synu (nazwanym nie przypadkiem Umiłowanym - por. w. 6 - ponieważ w ten sposób zostaje uwydatnione źródło miłości Boga do ludzi, jakim jest wzajemna miłość Ojca i Syna w Duchu Świętym). Bogactwo Jego łaski prócz Odkupienia zostaje wylane na wierzących w postaci mądrości i zrozumienia (por. w. 7-8) przez to, że

oznajmił tajemnicę swej woli według swego postanowienia, które przedtem w Nim powziął dla dokonania pełni czasów, aby wszystko na nowo zjednoczyć w Chrystusie jako Głowie: to, co w niebiosach, i to, co na ziemi (w. 9-10).

Według Apostoła dostępują udziału w Chrystusie ci, którzy zostali „z góry przeznaczeni zamiarem Tego, który dokonuje wszystkiego zgodnie z zamysłem swej woli" (w. 11) ${ }^{16}$. Do tych z góry przeznaczonych należą zarówno ci, którzy ,już przedtem nadzieję złożyli w Chrystusie" (w. 12), jak i ci, którzy usłyszawszy słowo prawdy - Dobrą Nowinę Zbawienia, uwierzyli i zostali naznaczeni pieczęcią Ducha Świętego (prawdopodobnie aluzja do chrztu), który jest zadatkiem (poręką) dziedzictwa w oczekiwaniu na Odkupienie (por. w. 13-14), czy może lepiej: który jest poręką dziedziczenia polegającego na swego rodzaju „przyswojeniu” (pozyskaniu dla siebie, wejściu w posiadanie) Odkupienia już dokonanego w Chrystusie ${ }^{17}$.

15 Tłumacząc dosłownie, słowo po słowie, otrzymamy według ks. Remigiusza Popowskiego: „przeznaczywszy nas ku usynowieniu przez Jezusa Pomazańca względem Niego, według - upodobania - woli Jego" - cyt. za: Grecko-polski Nowy Testament. Wydanie interlinearne z kodami gramatycznymi, tłum. R. Popowski, M. Wojciechowski, (Prymasowska Seria Biblijna), red. nauk. W. Chrostowski, Warszawa 1994 [dalej cyt. GPNT]. Por. również: Komentarz żydowski do Nowego Testamentu, tłum. Nowego Testamentu i kom. D. H. Stern, (Prymasowska Seria Biblijna), red. nauk. W. Chrostowski, tłum. A. Czwojdrak, Warszawa 2004 [dalej cyt. KZNT]: „Z góry postanowił, że przez Jeszuę Mesjasza będziemy Jego synami - tak jak Mu się spodobało i jak zamierzył".

16 Por. GPNT: „w którym i zostaliśmy_wybrani_losem, przeznaczeni według wcześniejszego ustawienia (Tego) - wszystko Działającego według postanowienia - woli Jego”; KZNT: „...my, których z góry wyłoniono zgodnie z zamiarem Tego, który sprawia wszystko według postanowienia swojej woli”.

Por. GPNT: „który jest poręką - dziedziczenia naszego, ku odkupieniu - pozyskania_dla_siebie...”; KZNT: „który zabezpiecza wasze dziedzictwo do chwili, aż wejdziemy w jego posiadanie..."; Pismo Święte Nowego Testamentu i Psalmy. Najnowszy przekład z języków oryginalnych z komentarzem. Opracowat Zespót Biblistów Polskichzinicjatywy Towarzystwa Świętego Pawta, Częstochowa 2005 [dalej cyt. PSNT]: „Duchem, który jest Poręczycielem naszego dziedzictwa, odkupienia tych, których On nabył...”. 
Zwraca uwagę w tym fragmencie zwłaszcza prapierwotność łaski Bożej, zgodnie z wolą Boga wyświadczonej ludziom. Wierzący zostają przez Boga wybrani i przeznaczeni ze względu na Chrystusa, który przecież na ziemi pojawi się dopiero w przyszłości, gdy Syn Boży stanie się człowiekiem. Już w tym widać, że wpływ Chrystusa obejmuje całe dzieje ludzkie i wszystkich ludzi, nawet jeśli w historii przed i po Chrystusie będzie się inaczej zaznaczał. Ludzkie poznanie Chrystusa w czasie, doświadczenie Jego zbawiennego wpływu, jest wypełnieniem się pozaczasowej (odwiecznej) woli Boga. Można to samo powiedzieć inaczej: tylko dlatego, że On tak postanowił „wcześniej” (nie sposób, ze względu na słabość ludzkiego rozumu i języka, nie mieszać tu porządków czasowego i wiecznego), możemy poznać Go ,później”. Święty Paweł pisał w innym miejscu o tym, że wszyscy zgrzeszyli i dostępują usprawiedliwienia z laski przez Odkupienie w Chrystusie ( $\mathrm{Rz} 3,23 \mathrm{n})$. Dotyczy to nie tylko tych żyjących po Chrystusie, ale w ogóle wszystkich ludzi. Bo, jak pisze Apostoł,

sprawiedliwość Jego względem grzechów popełnionych dawniej - za dni cierpliwości Bożej - wyrażała się w odpuszczaniu ich po to, by ujawnić w obecnym czasie Jego sprawiedliwość, i [aby pokazać], że On sam jest sprawiedliwy i usprawiedliwia każdego, który [żyje] dzięki wierze w Jezusa ( $R z$ 3,25n).

Wszyscy, także w przeszłości, dostępowali odpuszczenia grzechów ze względu na przyszłe odkupienie; wydarzenie Chrystusa dokonało się w czasie, ale obejmuje cały czas.

Bóg, według autora Listu do Efezjan, udzielił wierzącym „z wyżyn niebieskich wszelkiego błogosławieństwa duchowego w Chrystusie" w. 3, według PSNT, przy czym owe wyżyny niebieskie oznaczają „miejsce" przebywania Boga i uwielbionego Chrystusa po Jego prawicy (Ef 1,20). Jeśli „trudno dokładnie określić znaczenie tego sformułowania” użytego w wersecie 3., to jednak ,nie ulega wątpliwości, że wierzący już teraz uczestniczą w zbawieniu na wyżynach niebieskich", i że już w teraźniejszości przeżywają w pewien sposób swoją wieczność, skoro „Bóg wskrzesił wierzących razem z Chrystusem i posadził ich «na wyżynach niebieskich - w Chrystusie Jezusie»"18 (Ef 2,6). Jak zapewnia wierzących autor Listu do Kolosan: „umarliście bowiem i wasze życie jest ukryte z Chrystusem w Bogu" (3,3), po którego prawicy zasiada

18 Por. M. Y. MacDonald, List do Efezjan, tłum. T. Mieszkowski, [w:] W. R. Farmer (red.), Międzynarodowy komentarz do Pisma Świętego. Komentarz katolicki i ekumeniczny na XXI wiek, W. Chrostowski (red. wyd. pol.), tłum. H. Bednarek [i in.], Warszawa 2001, s. 1521 [dalej cyt. MKPS]. 
uwielbiony Chrystus (w. 1); gdy On się ukaże, wtedy i chrześcijanie razem z Nim ukażą się w chwale (w. 4).

\section{Realizacja planu w czasie}

List do Efezjan objawia, że Zbawienie człowieka - w Chrystusie! wynika $z$ i należy do odwiecznego planu Boga. Według Jana Pawła II:

Jest to plan uniwersalny, odnosi się do wszystkich ludzi stworzonych „na obraz i podobieństwo Boże” (por. Rdz 1, 26). Wszyscy, objęci „u początku” Boskim dziełem stworzenia, odwiecznie są też ogarnięci Boskim planem zbawienia, który ma się do końca objawić w „pełni czasu", wraz z przyjściem Chrystusa"19.

Apostoł narodów pisał o tajemnicy ( $\mu v \sigma \tau$ pıov) Bożej woli, która została oznajmiona (Ef 1,9). Według eschatologii żydowskiej Bóg miał oznajmić treść swoich tajemnic na końcu tego wieku ${ }^{20}$. Według komentatora Listu do Efezjan, by zrozumieć pojęcie mystērion użyte przez autora natchnionego, należy uwzględnić ,judaistyczny pogląd ze schyłku starożytności, że Boże tajemnice regulują bieg wszystkich spraw", a

Wszechwiedzący Bóg sprawuje kontrolę nad wszystkim, ponieważ w wieczności wyznaczył nieodwołalny bieg zdarzeń”, tak że świat ludzi i aniołów, i cały w ogóle kosmos (wszystko, co stworzone) „to sfery zdeterminowane przez jego wolę ${ }^{21}$.

Tajemnica (in. Sekret), czyli ukryty zamysł Boga wobec całego wszechświata, odsłania się przed wierzącymi „przez Boże działanie zgodnie ze zbawczą wolą Bożą, która objawia się w historii"22.

19 Jan Paweł II, encyklika Redemptoris Mater, nr 7 [dalej cyt. RM]. Korzystam z: Jan Paweł II, encyklika Redemptoris Mater (O błogosławionej Maryi Dziewicy w życiu pielgrzymującego Kościoła), www.opoka.org.pl. Warto byłoby się zastanowić nad związkiem pomiędzy stworzeniem a Zbawieniem. Być może nie mniejszą tajemnicąjest fakt, że Bóg stwarza każdego człowieka, choć stworzenie już się dokonało, od tego, że Bóg zbawia wszystkich ludzi, choć Zbawienie już się dokonało (w przypadku żyjących po Chrystusie) lub jeszcze się nie dokonało (dot.ludzi żyjących przed Chrystusem). Kto wie, czy pozornie mniejsze problemy w przyjęciu misterium stworzenia przez współczesnych nie wynikają z tego, że dziś wielu chrześcijan przyjęło deistyczny obraz Boga, który stworzywszy Adama i Ewę posługuje się odtąd naturalnymi procesami, np. ewolucją? Por. MKPS, s. 1521.

P. J. Kobelski, List do Efezjan, [w:] R.E. Brown, J. A. Fitzmyer, R. E. Murphy (red.), Katolickikomentarzbiblijny, red.wyd.pol. W. Chrostowski, (Prymasowska Seria Biblijna), red. nauk. W. Chrostowski, tłum. K. Bardski [i in.], Warszawa 2004, s. 1392.

22 M. Ernst, Tajemnica, tłum. T. Siemieniec, [w:] F. Kogler, R. Egger-Wenzel, M. Ernst (red.), Nowy leksykon biblijny, red. nacz. nauk. wyd. pol. H. Witczyk, Kielce 2011, s. 743. 
Bóg, który wybrane sługi powoływał i obdarzał łaską i Duchem Świętym już w łonie matki (Iz 49,1; Łk 1,15; Ga 1,15), swoją Służebnicę obdarzył specjalną łaską od pierwszej chwili poczęcia. Patrząc od strony Boga, można powiedzieć, że Bóg powołuje jeszcze przed stworzeniem człowieka, w swojej wiecznej woli, mówiąc językiem biblijnym: Bóg zna człowieka, zanim ten zostanie ukształtowany w łonie matki, i już „wtedy”, zanim ten się stanie, poświęca i powołuje do wybranego dzieła (Iz 1,5). Wszyscy czerpiemy z owoców odkupienia, każdy jest odkupiony w odwiecznej Bożej woli zanim został odkupiony w czasie; Chrystus nas odkupił zgodnie z odwieczną wolą Bożą, choć w czasie dopiero przyswajamy sobie to Odkupienie.

\section{Zdeterminowanie a wolność człowieka}

Oczywiście w tym momencie powinno pojawić się niepokojące pytanie o stosunek tego odwiecznego planu Bożego do wolności ludzkiej; czy Bóg sprawujący kontrolę nad wszystkim nie determinuje wolnej woli człowieka? I dalej: czy realizacja odwiecznie założonego planu nie oznacza po prostu predestynacji (Rz 9,19-21)? Tym bardziej, gdy weźmie się pod uwagę, że to Bóg jest w nas sprawcą nie tylko chcenia, ale i działania (Flp 2,13), a więc wszystkiego? Ale przecież z drugiej strony Paweł wzywa wierzących do działania, jakby ono zależało wyłącznie od nich; również Ojcowie Kościoła równoważyli „pogląd, że zbawienie pochodzi wyłącznie od Boga (...) ideą, że ludzkość jest wezwana do współdziałania z Bożą inicjatywą". Z kolei bez tej równowagi odczytany tekst „odegrał ważną rolę w kontrowersyjnej doktrynie Kalwina o predestynacji i w debatach na jej temat"23. Lekturę Listu do Efezjan należy czytać w kontekście całości Biblii (tzw. egzegeza kanoniczna ${ }^{24}$ ), zresztą nawet całościowo odczytany list ukazuje, że zbawienie ma zarówno charakter „odwieczności”, teraźniejszości (por. Ef 2,6) jak i przyszłości (Ef 1,13-14 i 4,30).

Wydaje się, że nie da się relacji predestynacja - wolna wola wyjaśnić inaczej niż w ten paradoksalny sposób: wszystko zależy od Boga, i wszystko od człowieka, a jedno drugiemu nie przeczy. Komentarz żydowski do Nowego Testamentu cytuje paradoksalną wypowiedź żydowskiego rabina Rabbiego Akiwy, która dobrze wydaje się odpowiadać logice Bosko-ludzkich tajemnic: „wszystko zostało przewidziane

\footnotetext{
$23 \quad$ MKPS, s. 1519.
}

$24 \quad$ Por. S.Zatwardnicki, Hermeneutyka wiary wnauczaniu papieża BenedyktaXVI, s. 124-134. „Egzegeza kanoniczna” to jedna z tzw. wielkich zasad interpretacji Pisma Świętego (por. ibidem, s. 123-174), których uwzględnienia wymaga „hermeneutyka wiary". 
i wolna wola została dana" ${ }^{25}$. Tak chyba należy patrzeć na relację Boży plan a ludzka wolność: Bóg czyni to, co tylko On może uczynić, a człowiek to, co do niego należy; przy czym nie mógłby człowiek czynić tego bez uprzedniej łaski Bożej. Jedno drugiemu nie przeczy: wolna wola nie przekreśla odwiecznego planu, z kolei Boski zamiar nie determinuje ludzkiej woli. Zamilknijmy przed tą tajemnicą, albo lepiej: medytujmy wyjątkowy jej wyraz, z jakim mamy do czynienia w przypadku Niepokalanie Poczętej (uczynimy to w dalszej części artykułu), oraz adorujmy tajemnicę zjednoczenia woli Boskiej i ludzkiej w Chrystusie, który stanowi fundament dla ludzkiej współpracy (w tym i Maryi) z Bogiem.

Mamy bowiem do czynienia z misterium niemniej tajemniczym od zjednoczenia dwóch natur, Boskiej i ludzkiej, w jednej Osobie Chrystusa, które to misterium zresztą wydaje się być modelem dla wszystkiego, co łączy w sobie sprawy Boskie i ludzkie. Wydaje się, że w próbie zrozumienia połączenia odwiecznego planu i ludzkiej woli nie ma innej drogi niż udać się do Chalcedonu i skorzystać z owego „bez zmieszania i bez rozdzielania”26. Tajemnicy to nie wyjaśni - jeśli pamiętać, że definicja chalcedońska raczej broni misterium Chrystusa niż go odsłania ${ }^{27}$ - ale pozwoli odeprzeć niewłaściwe próby rozwikłania. Jedną z nich jest predestynacja, na którą można patrzeć jak na swego rodzaju monofizytyzm (wszystko zależy od Boga), a drugą takie rozdzielenie („,nestorianizm”) odwiecznego planu Boga i wolnej woli ludzkiej, że przestają one mieć ze sobą jakikolwiek związek; w praktyce właśnie ta postawa wyraża się patrzeniem na Odkupienie jedynie z perspektywy czasu. Zastosowana z kolei do Maryi - prowadzi do zapomnienia, że Jej fiat nie było możliwe bez uprzedniego Odkupienia.

KZNT, s. 571.

26 Por. Wyznanie wiary Soboru Chalcedońskiego, 451 r., [w:] Breviarium fidei. Wybór doktrynalnych wypowiedzi Kościoła, oprac. S. Głowa, I. Bieda, Poznań 1998, nr 89: „....jednego i tego samego Chrystusa Pana, Syna Jednorodzonego należy wyznawać w dwóch naturach, bez zmieszania, bez zmiany, bez rozdzielania i rozłączania".

27 Warto pamiętać, że w soborowych sformułowaniach posłużono się samymi negatywnymi określeniami, przez co po pierwsze została podkreślona tajemnica dokonującego się zjednoczenia natur, a po drugie w ten sposób definicja odpiera niewłaściwe wyjaśnienia misterium Chrystusa - por. Dokumenty Soborów Powszechnych. Tekst grecki, tacinski, polski. Tom I, Nicea I, Konstantynopol I, Efez, Chalcedon, Konstantynopol II, Konstantynopol III, Nicea II (325-787) (Źródła Myśli Teologicznej, 24), układ i oprac. A. Baron, H. Pietras, Kraków 2007, s. 223, przypis 72e. 


\section{Tajemnica komunii woli}

Również w ziemskim życiu Tego, który stał się nam podobny we wszystkim z wyjątkiem grzechu (por. Hbr 4,15) daje się zauważyć - np. w modlitwie w Getsemani (zob. Mt 26,36-46 i par.) - owo połączenie realizacji odwiecznego planu Boga (przyjście Syna „dla tej godziny” - por. J 12,27), i działania człowieka Jezusa w czasie, bez którego odwieczna wola Boża nie znalazłaby realizacji na ziemi, a zatem nie byłaby możliwa w ogóle do podjęcia przez Boga w wieczności. Wola Boska nie determinuje ludzkiej, owszem może się wypełnić tylko dzięki temu, że wola natury ludzkiej zostaje poddana woli Osoby Bożej. Zagadnieniem relacji pomiędzy wolą ludzką a Boską w Chrystusie zajął się III Sobór w Konstantynopolu, który formułę Chalcedonu („bez zmieszania i bez rozdzielania”) zastosował również do „dwóch woli” i „dwóch działan" 28 , które choć pozostają oddzielne, tworzą rzeczywistą jedność. Dzieje się to dzięki temu, że nie na sposób naturalny, ale na drodze wolności ludzka wola idzie za wolą Bożą, dzięki czemu dokonuje się ich zjednoczenie ${ }^{29}$. Zbawienie ludzi, które „było chciane przez Boską Osobę za pośrednictwem ludzkiej woli" ${ }^{30}$, dokonało się w konkretnej egzystencji Jezusa przez posłuszne poddanie się woli ludzkiej - woli Syna (tożsamej z wolą Ojca) ${ }^{31}$.

Właśnie w zagadnieniu dwóch sposobów chcenia i działania w Chrystusie - wyciągał wnioski kardynał Schönborn - staje się bardziej widoczne, że osoba Syna Przedwiecznego może aż do samych korzeni przenikać ludzką rzeczywistość Chrystusa, nie niszcząc jej ani w niczym nie zmieniając ${ }^{32}$.

28 Por. Sobór Konstantynopolitański (680-681). Wykład wiary, nr 14.16 i 19, [w:] Dokumenty Soborów Powszechnych, op. cit.

29 Por. J. Ratzinger, Chrystus i Jego Kościót, tłum. W. Szymona, Kraków 2005, s. 117. Por. idem, Patrzeć na przebitego. Szkice o chrystologii duchowej, tłum. J. Merecki, Kraków 2008, s. 35.

30 Międzynarodowa Komisja Teologiczna, Wybrane zagadnienia chrystologii (1979), II, C. Korzystam z wydania: Wybrane zagadnienia chrystologii (1979), tłum. J. Bielecki, [w:] J. Królikowski (red.), Od wiary do teologii. Dokumenty Międzynarodowej Komisji Teologicznej 1969-1996, Kraków 2000, s. 111-132.

31 Benedykt XVI, Audiencja generalna: ,»Tak“ powiedziane Bogu szczytem wolności”(01.02.2012), L’OssRom (PL) (2012) nr 4, s. 45: ,w Nim naturalna wola jest w pełni włączona w nastawienie, które jej daje Osoba Boska. Jezus przeżywa swoje życie zgodnie z tym, co jest istotą Jego Osoby: jest Synem Bożym. Jego ludzka wola zawiera się w »Ja« Syna, zawierzającym się całkowicie Ojcu”. 
Jeśli wola ludzka znalazła swoje urzeczywistnienie dopiero w jedności Boskiej Osoby Syna, można to wytłumaczyć - mówił Benedykt XVI w odwołaniu do św. Maksyma Wyznawcy - jedynie tym, że została stworzona przez Boga jako nastawiona na wolę Bożą, i dlatego w odpowiedzi „tak” danej Bogu, w poddaniu się woli Bożej znajduje swoje pełne urzeczywistnienie (staje się „Boska”) ${ }^{33}$. Koniecznie należy podkreślić, że właśnie i jedynie dzięki posłuszeństwu Drugiego Adama zostaliśmy - potomkowie zbuntowanego pierwszego Adama - zbawieni i uzdolnieni do wypowiadania naszego fiat Bogu:

Dramat naszego odkupienia polega na tym, że Jezus ciągnie ku górze naszą wolę, nasz sprzeciw wobec woli Bożej, a także nasz sprzeciw wobec śmierci oraz grzechu, i łączy go z wolą Ojca: „nie moja wola, lecz Twoja”. W tej przemianie „nie” w „tak”, w tym włączeniu woli stworzenia w wolę Ojca przemienia On ludzkość i nas zbawia ${ }^{34}$.

Po upadku Adama to właśnie wola ludzka potrzebowała Zbawienia, na co zwracał uwagę broniący ludzkiej woli w czasie sporów chrystologicznych św. Maksym Wyznawca ${ }^{35}$. Tak więc ludzkie fiat (również Maryjne) jest możliwe tylko dzięki temu, że Chrystus zbawił wolę człowieka. $Z$ tej perspektywy można również patrzeć na stosunek odwiecznej woli Bożej do wolnej woli człowieka; na tym polega Odkupienie, że zbawiony człowiek jest wezwany do współdziałaniu w Zbawieniu, co jest możliwe tylko dzięki uprzedniemu Odkupieniu jego woli. Predestynacja nie determinuje, owszem właśnie doprowadza wolę człowieka do wolności, dzięki czemu jest możliwa realizacja w czasie odwiecznego planu ${ }^{36}$.

Benedykt XVI, „Tak” powiedziane Bogu szczytem wolności”, op. cit., s. 45. W swojej książce Jezus z Nazaretu Papież podkreślał, że w Chrystusie istnieją dwie wole, ale ponieważ istnieje tylko jedna Osoba, w takim razie jedna wola osobowa obejmuje wolę natury ludzkiej; jest to „możliwe bez zniszczenia istotnego elementu ludzkiego, ponieważ na mocy samego stworzenia wola ludzka jest ukierunkowana na wolę Bożą; przez przylgnięcie do woli Bożej nie ulega zniszczeniu, lecz osiąga własną doskonałość” - J. Ratzinger (Benedykt XVI), Jezus z Nazaretu, cz. 2: Od wjazdu do Jerozolimy do Zmartwychwstania, tłum. W. Szymona, Kielce 2011, s. 174.

Benedykt XVI, Audiencja generalna w Wielka Środę: „Tajemnica Wielkiego Tygodnia umacnia wiare” (20.04.2011), „L'Osservatore Romano” (2011) nr 6, s. 31 .

35 Por. Ch. Schönborn, Przebóstwienie, życie i śmierć, tłum. W. Szymona, Poznań 2001, s. 44.

36 Por. K. Rahner, Pisma wybrane, t.2, wyb. tekstów i tłum. G. Bubel, Kraków 2007, s. 220-221 [dalej cyt. RPW]: ,...wola zbawcza Boga jako to, co pierwotne i ostateczne, ogarnia każdego człowieka, wyprzedzając faktyczne zmazanie grzechu pierworodnego poprzez chrzest czy niesakramentalne usprawiedliwienie". 


\section{Odsłonięcie Bożego planu w życiu Maryi}

\section{Wyjątkowe powołanie Matki Bożej}

Jeśli Boża tajemnica powzięta odwiecznie „zostaje objawiona w trak- Mariologia cie realizacji Bożego planu zbawienia"37, wolno założyć, że w życiu Maryi powołanej do wyjątkowej misji i obdarzonej specjalnymi przywilejami ze względu na współpracę w wypełnieniu planu Zbawienia, tajemnica ta odsłoni się w sposób maksymalny. Nie przypadkiem Katechizm nazywa Ją „krzakiem gorejącym ostatecznej teofanii” ${ }^{38}$. „Niewysłowiony Bóg - według Piusa IX - od początku i przed wiekami wybrał matkę dla swego Jednorodzonego Syna i przeznaczył Ją, aby w błogosławionej pełni czasów stał się w Niej ciałem..."39. Prapierwotność łaski Bożej dotycząca każdego człowieka daje o sobie znać zwłaszcza w przypadku Dziewicy wybranej zgodnie z odwiecznym planem do odegrania w nim roli specjalnej. ,W całokształcie tego planu, który ogarnia wszystkich ludzi - pisał papież z Polski - szczególne miejsce zajmuje «niewiasta» jako Matka Tego, z którym Ojciec odwiecznie związał dzieło zbawienia" ${ }^{40}$. Wolno w słowach anioła „znalazłaś bowiem łaskę u Boga" (Łk 1,30) słyszeć nie przede wszystkim owoc współpracy Maryi z Bogiem, ale właśnie uprzednie wybranie, jeszcze Nim jakikolwiek wysiłek z Jej strony został podjęty.

Papież w wyrażeniach „łaski pełna” (por. Łk 1,28) oraz „,błogosławiona między niewiastami” (por. Łk 1,42) widział wyraz „wszelkiego błogosławieństwa" (w rozumieniu: mającego w sobie pełnię) duchowego, o którym pisał autor Listu do Efezjan, skierowanego do wszystkich ludzi i osiągającego miarę szczególną i wyjątkową w przypadku Maryi $^{41}$. Jeśli według bogactwa Jego łaski ludzie otrzymali odkupienie przez krew Chrystusa (por. Ef 1,7), to owo bogactwo objawiło się w odkupieniu Bogurodzicy w sposób wznioślejszy, bowiem nie tylko że została uchroniona od zmazy grzechu pierworodnego, ale również ubogacona od poczęcia świętością pochodzącą od Chrystusa, i napełniona przez Ojca wszelkim błogosławieństwem w Chrystusie, stosownie do odwiecznego wybrania Jej do tego, aby była święta i nieskalana (por. Ef 1,3-4; KKK 492).

\footnotetext{
$37 \quad$ PSNT, s. 435.

$38 \quad$ KKK 724.

39 Bulla papieża Piusa IX Ineffabilis Deus, nr 524.

$40 \quad$ RM 7.

$41 \quad$ Por. RM 8.
} 


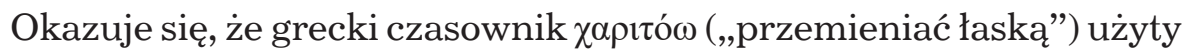
jest jedynie w dwóch miejscach Nowego Testamentu: właśnie w Liście do Efezjan, gdzie jest mowa o chwalebnym majestacie łaski Boga Ojca,

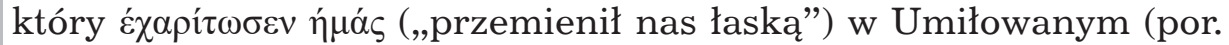
1,6), oraz w odniesieniu do Niepokalanej, która została $\kappa \varepsilon \chi \alpha \rho ı \omega \mu \varepsilon ́ v \eta$ (,przemieniona łaską”, por. Łk 1,28). Pomimo różnicy pomiędzy przemienieniem Niepokalanej (należy do przeszłości, ale nie jest związane z określonym momentem czasu, bowiem Odkupienie jeszcze nie dokonało się w czasie) a przemienieniem pokalańców (czas przeszły wskazuje na odwołanie się do określonego czynu z przeszłości), należy zauważyć wspólny Jej i nam plan Ojca, który w Chrystusie prowadzi do tego, abyśmy byli święci i nieskalani. Pełna łaski jest nieskalana optymalnie (Niepokalane Poczęcie), a my zmierzamy do uzyskania stanu niepokalania ${ }^{42}$.

\section{Warunkiem Bogorodzicielstwa - uprzednie Odkupienie}

Warto podkreślić, że nie mogłaby Maryja zostać Matką Boga, gdyby nie Niepokalane Poczęcie, które według Hansa Ursa von Balthasara nie oznacza „nic innego, jak konieczny warunek absolutnego charakteru Jej «tak»”, bo „gdyby ono było w jakiś sposób skażone tą pierworodną winą, wtedy nie byłoby możliwe to pełne otwarcie się na Boga i oddanie się Jemu do dyspozycji" ${ }^{43}$. Również z perspektywy historii Zbawienia - jeśli ma ono być czymś rzeczywistym - konieczne jest, by Rodzicielka Boga była absolutnie wolna od grzechu, „w chrystogenezę nie może się wsączyć nic z grzechu lub rzeczywistość rozdwojona na dobro i zło moralne”, ponieważ „odkupienie, miłosierdzie i zbawienie nie jest «kompromisem», lecz czystym darem, miłością, udoskonaleniem stworzenia" 44 .

Jak pierwsza Ewa została stworzona jako odpowiednia pomoc dla Adama (por. Rdz 2,18), tak druga Ewa, jak słusznie nazwali Maryję Ojcowie Kościoła, staje się odpowiednią pomocą dla Chrystusa Drugiego Adama. Zgodnie z paradygmatem zapowiedzianym w Protoewangelii $(\mathrm{Rdz} 3,15) \mathrm{w}$ historii Zbawienia odegrać muszą rolę dwie główne Postaci - w pełnym triumfie Syna nad wężem uczestniczy również Niewiasta. Zatem na Niepokalane Poczęcie słusznie jest spojrzeć i od tej strony, którą zaproponował John Henry Newman - Maryja

\footnotetext{
42 Por. PWU, s. 41-42.

43 J.Ratzinger(Benedykt XVI), H. Urs von Balthasar, Maryja w tajemnicy Kościoła, tłum. W. Szymona, Kraków 2007, s. 92-93. 
powołana do współpracy w odkupieniu świata musi być wyposażona w łaskę nie mniej niż Ewa, która miała pomagać swojemu mężowi. Znany konwertyta z protestantyzmu na katolicyzm pisał: „Nie wiem, jak oprzeć się tej argumentacji, bo przecież jest ona dosłownie i po prostu doktryną o $" 45$.

Według kardynała Ratzingera słowa Listu do Kolosan mówiące o tym, że życie wierzących ukryte jest z Chrystusem w Bogu (por. 3,3), wskazują na istnienie czegoś „,w rodzaju «wniebowzięcia» ochrzczonych, o którym wyraźnie mówi List do Efezjan: »Bóg wzbudził was z martwych, dozwolił zasiadać na niebiosach w Chrystusie Jezusie « $(2,6)$ ", skutkiem czego każdy ochrzczony ,,jest, i tak dalece, jak nim jest, włączony już teraz we Wniebowstąpienie i żyje w Nim, w uwielbionym Panu, swoim ukrytym (prawdziwym) życiem" ${ }^{46}$. Jeśli założyć, że wiara Maryi była nieograniczona (por. Łk 1,45), wtedy konsekwentnie należy przyjąć, że w osobie Maryi to życie w uwielbionym Panu osiągnęło stopień najwyższy ${ }^{47}$. Innymi słowy, dostąpiła Maryja jako „doskonała chrześcijanka" pełni tego - dodawał kardynał w rozmowie z niemieckim dziennikarzem - co dla wszystkich wierzących ,jest skutkiem chrztu, mianowicie zamieszkała («ma siedzibę») z Bogiem «w niebie» (Bóg jest niebem!)”48. W ten sposób koniec Jej życia (Wniebowzięcie) wiąże się z początkiem (Niepokalane Poczęcie) ${ }^{49}$, a odwieczna Boża wola spotyka się w sposób doskonały z jej realizacją w życiu wierzącego. To jedynie w Niej w pełni, jak to określił papież Franciszek, „wierzący jest całkowicie zaangażowany w swoje wyznanie wiary" ${ }^{50}$. Jeśli misterium oznacza „coś przedtem ukrytego, a obecnie odsłoniętego" ${ }^{1}$,

45 J.H.Newman, Odnajdywanie Matki. List do wielebnego Bouverie Puseya doktora teologii dotyczacy jego ostatniego Eireniconu, tłum. W. Życiński, Niepokalanów 1986, s. 65.

J. Ratzinger (Benedykt XVI), Wzniosła Córa Syjonu, tłum. J. Królikowski, Poznań 2002, s. 52 [dalej cyt. WCS].

Por. WCS, s. 52.

J. Ratzinger, P. Seewald, Bóg $i$ świat. Wiara $i$ życie $w$ dzisiejszych czasach. Zkardynatem Josephem Ratzingerem Benedyktem XVIrozmawia Peter Seewald, tłum. G. Sowinski, Kraków 2005, s. 281.

Związek ten można, według sugestii Ratzingera, ,opisać być może w taki sposób: gdzie jest pełnia łaski, tam jest pełnia zbawienia. Gdzie łaska nie znajduje się na granicy równoczesnej sprawiedliwości i grzeszności, ale jest czystym »tak«, tam nie ma miejsca na śmierć - służebnicę grzechu" (WCS, s. 51).

$50 \quad$ Franciszek, encyklika Lumen fidei, nr 59. Korzystam z wydania: Franciszek, encyklika Lumen fidei (O wierze), Wrocław 2013. 
to w wydarzeniach z życia Maryi mamy do czynienia z najpełniejszym odsłonięciem tajemnicy Bożego planu.

\section{Współpraca Niepokalanej w Odkupieniu}

Z naszej perspektywy wydaje się sprzeczne, że można być odkupionym „wstecz”. Jednak Bóg okazuje się Panem również czasu, który z kolei jawi się nie jako przeciwieństwo wieczności, ale jako rzeczywistość w pewnym sensie ,przyjęta” przez wiecznego Boga. Bóg nie tyle żyje poza czasem, ile raczej ma dostęp do czasu wiecznie i w każdej chwili. Wskazuje na to Wcielenie, w którym wieczny Bóg staje się podlegającym czasowi człowiekiem, a zatem wieczne Słowo włącza czas w „przestrzeń” wieczności. Czas i wieczność spotykają się w jakiejś misteryjnej syntezie, bo, jak pisze komentator chrystologii Ratzingera, „Chrystus staje się mostem pomiędzy czasem a wiecznością”; okazuje się, że „wieczność Boga nie jest po prostu bezczasowością, negacją czasu, ale jest władzą nad czasem, która urzeczywistnia się jako bycie «z» czasem i bycie «w» czasie" ${ }^{2}$. Ten, który jest wieczny, posiada jednak czas, tak że możemy w czasie spotykać się z Nim nam współczesnym, ale „w Nim, który wraz z nami jest w czasie, dotykamy jednak zarazem Tego, który jest wieczny, gdyż wraz z nami jest On w czasie, a z Bogiem w wieczności" ${ }^{53}$. Dlatego jesteśmy w stanie przyjąć w którymś momencie naszego życia to Odkupienie, które już się dokonało (a żyjący przed Chrystusem mogli zostać zbawieni, nim Odkupienie zrealizowało się w czasie), do czego zostaliśmy wybrani odwiecznie, a więc zanim Odkupienie w historii się dokonało.

Ale tu zaczyna się piętrzyć przed ludzkim rozumem jeszcze trudniejszy do pojęcia paradoks. Otóż Niepokalanie Poczęta korzysta z owoców Odkupienia zależnych od tego, co sama uczyni w przyszłości, z kolei Jej zgoda na Wcielenie będzie możliwa tylko dzięki Chrystusowemu fiat, którego nie byłoby, gdyby nie Jej fiat. Uprzednie Odkupienie jest tym samym następstwem tego, co dokona się później, dzięki wcześniej wyświadczonej łasce Odkupienia, która - filozofował Jean Guitton -

zawsze obecna w Bożej wszechwiedzy, górująca nad wszystkimi czasami, a zatem zdolna do retroaktywnego działania sprawiła, że Maryja

52 F. K. Chodkowski, „Ty jesteś Chrystus Syn Boga żywego”. Zarys chrystologii Josepha Ratzingera, Poznań 2007, s. 113.

53 J. Ratzinger, Wprowadzenie w chrześcijaństwo, tłum. Z. Włodkowa, Kraków 2012 , s. 334 . 
była zawsze pełna łaski, a tym samym dopuściła ją do współudziału w przyszłej Męce, której pierwszym owocem była Jej niewinnośćc ${ }^{4}$.

Przywilej Niepokalanego Poczęcia należy oczywiście wiązać z powołaniem do Bogorodzicielstwa ${ }^{55}$, wolno więc powiedzieć, że przyszła Matka Boga poczyna się jako odkupiona ze względu na zgodę, którą wyrazi w czasie Zwiastowania, a dzięki której pocznie się Jezus ${ }^{56}$. Dobrze oddać to „sprzężenie zwrotne” pomiędzy Odkupieniem a Bogorodzicielstwem paradoksem zapisanym przez Karla Rahnera: „Jako Matka Boga jest więc Maryja w najdoskonalszy sposób Odkupioną i odwrotnie jako w najdoskonalszy sposób Odkupiona jest ona Matką Boga"57. Bezwarunkowa wiara Maryi jest związana z łaską Odkupienia, i właśnie przez to posiada dla Niej i dla nas znaczenie zbawcze; jest najdoskonalej odkupioną właśnie dlatego, że dzięki temu Zbawicielowi dane jest Jej znaleźć się w „pełni czasu” (por. Ga 4,4-5), i zostać dopuszczoną i wezwaną do tego, by dzięki Jej wolności mogło dokonać się zbawienie świata ${ }^{58}$.

\section{Wola Niepokalanej a wola Boża}

Warto podkreślić, że w przypadku Maryi determinacja wynikająca z odwiecznego Bożego planu i wolna wola spotykają się w sposób doskonały (czyli najbardziej paradoksalny): wybrana na Matkę, Niepokalanie Poczęta, „Cała Święta”, jak Ją nazywają Ojcowie Kościoła, jakby utworzona przez Ducha Świętego ${ }^{59}$, przyjmuje Bożą „predestynację” na drodze wolności, co w praktyce oznacza bolesne dostosowywanie

54 J. Guitton, Maryja, tłum. T. Dmochowska, Warszawa 1956, s. 165.

55 Łaska Niepokalanego Poczęcia nie wyczerpuje się oczywiście w samej wolności od grzechu pierworodnego, ale wiąże się z uczestnictwem w życiu Chrystusa. Ojcowie Soborowi, razjeszcze przypomnijmy, mówią o ścisłym i nierozerwalnym węźle, jakim Matka jest zjednoczona z Synem, a dar ten i największa godność wynikają właśnie z faktu, że jest Rodzicielką Syna, a zatem umiłowaną Córką Ojca i przybytkiem Ducha Świętego (por. LG 53).

Według francuskiego filozofa Maryja w czasie Zwiastowania „czuje, że została wybrana przez Tego, który ma się stać Jej Synem. Tym właśnie różni się od wszystkich innych matek. Czas się cofa” (J. Guitton, Maryja, op. cit., s. 55). Ten paradoks znalazł swój wyraz w liturgii: Maryja „otrzymuje życie od Tego, któremu w porządku ziemskiego rodzenia sama dała życie jako Matka”, dlatego - przypominał Jan Paweł II - „liturgia nie waha się nazywać Ją «Rodzicielką swego Stworzyciela»" (RM 10).

RPW, s. 217. 
woli Niepokalanej do Bożych planów: „Boska misja Jezusa rozsadza wszelkie ludzkie miary i dla człowieka staje się ciągle mroczną tajemnicą"60. Niepokalanie Poczęta być może nie zdawała sobie sprawy z niepokalanego poczęcia, w każdym razie na pewno nie uświadamiała sobie w pełni i bez wątpienia nie umiałaby sformułować tego przywileju w teologicznych pojęciach. Nie komu innemu, ale właśnie Jej „najpełniej została objawiona tajemnica” Boskiego synostwa Jezusa, jednak i Matka Boża „z tajemnicą tą obcowała tylko przez wiarę"61.

Łaska Boża „może wprawdzie wzmocnić wiarę, jednak jej celem nie jest zastąpienie lub pomniejszenie znaczenia wiary" ${ }^{2}$. Łaska nie zastępuje wolnej woli, sprawia za to,

że wolna wola Maryi jest w stanie rzeczywiście korzystać z wolności. Maryja realizuje możliwości swojej wolności poprzez łaskę, która wyzwala Jej wolność (...) Tak rozumiana wolność Maryi jest wolnością wyzwoloną przez łaskę. To Bóg podtrzymuje Maryję w Jej wolnym działaniu, tak jak podtrzymuje Jej egzystencję w bycie ${ }^{63}$.

Nie tylko łaska nie wyklucza współpracy ze strony człowieka, ale właśnie ją umożliwia. „Maryja za łaską Boga jest tym, czym jest (por. 1Kor 15,10), ale też do Niej można odnieść dalszą część wypowiedzi św. Pawła: «pracowałem więcej od nich wszystkich, nie ja, co prawda, lecz łaska Boża ze mną» (1Kor 15,10)"64.

Dlatego bez „pobożnych” uprzedzeń odczytana Ewangelia pozwala zauważyć w ziemskim życiu Maryi ową „pracę”, o której pisał Apostoł, tyle że pewnie była to praca bardziej wewnętrzna. Papież Paweł VI przypominał, że „wzniosła świętość błogosławionej Dziewicy Maryi była nie tylko wyjątkowym darem Boskiej hojności, lecz także owocem ustawicznej i wspaniałomyślnej uległości Jej wolnej woli wewnętrznej natchnieniom Ducha Świętego"65. Realizacja Bożej woli nieustannie odczytywanej powoduje w człowieku, ,swoisty trud serca, jaki związany jest z «ciemną nocą wiary» - używając słów św. Jana od Krzyża - jakby z «zasłoną», poprzez którą wypada przybliżać się do Niewidzialnego

60 J. Ratzinger (Benedykt XVI), Jezus z Nazaretu. Dzieciństwo, tłum. W. Szymona, Kraków 2012, s. 165.

61 RM 17.

L. Scheffczyk, Maryja. Matka i Towarzyszka Chrystusa. Podręcznik mariologii, tłum. J. Tumielewicz, Kraków 2004, s. 52-53.

63 PWU, s. 194.

64 Ibidem, s. 200.

65 Paweł VI, adhortacja apostolska Signum magnum, nr 4. Korzystam z: Paweł VI, adhortacja apostolska Signum magnum (O czci i naśladowaniu Najświętszej Panny Maryi, Matki Kościoła i wzoru wszystkich cnót), www.opoka.org.pl. 
i obcować z tajemnicą"66. Postępuje więc Niepokalanie Poczęta naprzód w pielgrzymce wiary i utrzymuje zjednoczenie z Synem aż do Krzyża ${ }^{67}$, a tam „wchodzi w stan najgłębszej kenozy i pogrąża się w absolutnej ciemności”, co staje się Jej „pełnym udziałem w ogołoceniu się Jezusa (Flp 2,5-8)"68. Najdoskonalej odkupiona zostać musi przecież dopuszMariologia czona najgłębiej do tajemnicy Odkupienia, jeśli odkupienie nie ma być czymś narzuconym przez Boga „z zewnątrz”.

Nie wolno Niepokalanego Poczęcia widzieć ,jako mechanicznej, odgórnej predestynacji do świętości i do macierzyństwa Bożego", za to należałoby w odwiecznym wyborze Boga widzieć również odwieczne przewidzenie „Jej woli osobowej, Jej świata osobowego, a więc wolnego. Maryja nie była rzeczą ani narzędziem. Zostało przewidziane również Jej fiat, cała Jej osoba, Jej odpowiedź życiem, osobistą świętością i niepowtarzalnym pragnieniem Boga na ziemi" ${ }^{69}$. Dopiero synteza jednego z drugim pozwala dostrzec zarówno szczególne powołanie Boże, jak i wyjątkową dyspozycję, jaką Bóg znalazł w Dziewicy; trzeba podkreślić, że Bóg wiedział, kogo wybrać na Matkę Syna, tylko Ona jedna mogła się nią stać. Nie jest Maryja, jak chciał Marcin Luter, jedynie warsztatem, w którym Bóg pracował ${ }^{70}$, stała się Matką Chrystusa nie z powodu swojej „bierności”, owszem właśnie dzięki wolnemu aktowi „przyjęła sercem i ciałem Słowo Boże"71. W analogii do tego, co wyżej powiedziano o Jezusie, można powiedzieć, że czynnie współpracowała z odwiecznym planem, choć - nie wolno zapomnieć - korzystała przy tym z owoców odkupienia. Dlatego św. Łukasz najpierw podkreślił pełnię łaski (por. Łk 1,28), a dopiero potem opowiedział o Amen Maryi ${ }^{72}$. Dzięki temu ,w tej Jej godzinie życia, dla której istniała, zostało zawarte ostateczne i wieczne przymierze między Bogiem a ludzkością"73.

RM 17.

Por. LG 58.

J.Ratzinger(Benedykt XVI), H. Urs von Balthasar, Maryja wtajemnicy Kościoła, op. cit., s. 43.

BMB, s. 134.

Por. M. Luter, Komentarz do „Magnificat” (1521), [w:] Teksty o Matce Bożej. Chrześcijaństwo ewangelickie (Beatam Me Dicent..., 10), tłum. E. Adamiak i in., red. serii: S.C. Napiórkowski, Niepokalanów 2000, s. 135.

LG 53.

Por. PWU, s. 201.

RPW, s. 216. 


\title{
Zakończenie: Niepokalany wyjątek od reguły
}

Jak już wspomniano, w szczególnym powołaniu Niepokalanie Poczętej, wolno doszukiwać się prawdy o powołaniu każdego chrześcijanina. Na Maryję trzeba bowiem patrzeć zarówno jak na siostrę (ciągłość powołania Jej i naszego), jak i na Matkę (nieciągłość między powołaniem Maryi i pozostałych wierzących). Dzięki „darowi szczególnej łaski znacznie przewyższa wszystkie inne stworzenia, niebieskie i ziemskie" "44, ale nie traci z nimi kontaktu; jeśli Bóg obdarza kogoś wyjątkowym przywilejem - świadczy o tym cała historia Zbawienia - to wybranie to służy właśnie innym. W Niepokalanej Matce i dzięki Niej (jako Matka rodzi synów) widać, jak w lustrze (raczej: w soczewce), kim jesteśmy jako chrześcijanie. Jest różna od nas i taka sama, jest bowiem naszą Matką i siostrą, w Jej powołaniu przewyższającym nasze przegląda się nasze wybranie i nabiera znaczenia. „Matka Pana jest doskonałą ikoną wiary"75. Kto udaje się w drogę ku Matce, odnajduje również siebie, a w wyjątkowej relacji Niepokalanej i Boga odsłania się model obowiązujący wszystkich wierzących ${ }^{76}$. Rozważanie dogmatu pod kątem wyjściowych problematycznych kwestii prowadzi do następujących wniosków.

\section{Łaska i wolność nie sprzeciwiają się}

Wola Boska i ludzka, zgodnie z paradygmatem chalcedońsko-konstantynopolitańskim, istnieją nie „obok” siebie, a tym bardziej nie

\author{
$74 \quad$ LG 53. \\ $75 \quad$ Franciszek, encyklika Lumen fidei, nr 58.
}

76 Maryja została odkupiona w sposób wznioślejszy, bo „czyż nie większą przysługę czyni ten - tłumaczył św. Maksymilian - kto usuwa kamień z drogi, by drugi się nie potknął i nie upadł, aniżeli ten, który upadłego już podnosi?" (M.M. Kolbe, Pisma. Cz. II, op. cit., s. 352). Również Karl Rahner odwoływał się do podobnej ilustracji: „Pozostać w postawie stojącej czy też ponownie powstać - obie rzeczywistości są łaską, wypływającą ze Zbawienia. Jeśli zaś stwierdzenie to jest prawdziwe, to w konsekwencji zbawiające zachowanie od grzechu pierworodnego jest najradykalniejszym i najbardziej błogosławionym sposobem odkupienia” (RPW, s. 222). Jeśli jednak Niepokalane Poczęcie ma stanowić jakiś niedościgły model obowiązujący wszystkich wierzących, trzeba $\mathrm{w}$ tej formie odkupienia dostrzec jeszcze coś innego. Dla jezuity z faktu, że Maryja jest w najdoskonalszy sposób odkupioną wynika, że jest Ona „wzorcem i praobrazem przypadku Odkupienia w najgłębszym tego słowa znaczeniu", przy czym „tajemnica Niepokalanego Poczęcia Maryi nie może polegać tylko na tym, że Maryja jedynie z punktu widzenia czasu wcześniej niż my doznała działania łaski Bożej. Różnica ta musi leżeć o wiele głębiej, i ta głębsza różnica musi warunkować różnicę czasową" (ibidem, s. 217 i 219). 
przeciw sobie, ale mogą się jednoczyć nie mieszając się i nie zmieniając swoich właściwości; więcej nawet, by w ogóle była możliwa wola prawdziwie ludzka, potrzeba, by spotkała się z wolą Boską. Wolno w doktrynie Niepokalanego Poczęcia słyszeć Dobrą Nowinę o tym, że „łaska Boża działała w sposób wystarczający, by wzbudzić odpowiedź, że łaska i wolność, że łaska i bycie sobą, rezygnacja i spełnienie tylko pozornie sprzeciwiają się sobie, gdy tymczasem warunkują się i wzajemnie zakładają"77. Maryja jest pierwszą z osób ludzkich, w których to zjednoczenie dokonało się w sposób doskonały, na wzór tego, co dokonało się w Osobie Wcielonego Słowa ${ }^{78}$.

\section{Bosko-ludzka współpraca w Zbawieniu}

Niepokalane Poczęcie jest wyjątkowym przejawem Bosko-ludzkiej współpracy w dziele Zbawienia. Jak się okazuje, nie chodzi o wybór pomiędzy Zbawieniem z łaski albo z uczynków, ale o Zbawienie rozumiane jako dar łaski, która wzbudza w człowieku możliwość współdziałania z Bogiem. Można powiedzieć, że Bóg nie zbawia człowieka bez człowieka, przy czym udziału człowieka i Boga w procesie zbawczym nie wolno widzieć z perspektywy „przeciągania liny” (im większy wkład człowieka, tym mniejszy Boga, i vice versa). Nie wolno przeciwstawiać sobie łaski i uczynków, owszem należy widzieć łaskę jako obejmującą i warunkującą również pozytywny wkład człowieka. Chodzi o zachowanie prawdziwości Bożej łaski oraz prawdziwości ludzkiej odpowiedzi na nią (analogia do chalcedońskiego „prawdziwy Bóg i prawdziwy człowiek"). Tylko tak rozumiane zbawienie może być zbawieniem z łaski, a jednocześnie nie jest czymś narzuconym siłą (predestynacja). Nic o nas bez nas, można by rzec.

Odkupiona w sposób wznioślejszy zostaje powołana do wznioślejszego uczestnictwa w dziele Zbawienia; korzystając z jego owoców, umożliwia Odkupienie przez to, że staje się Matką Boga. Jest to powołanie

77 WCS, s. 47.

78 Takie rozumienie relacji między wolą Boga a człowieka stanowi, jak sądzę, dobry punkt wyjścia do ekumenicznego spotkania z chrześcijanami prawosławnymi. Większość z nich jest przeciwna katolickiemu rozumieniu dogmatu o, a część z nich, jeśli przyznaje Maryi bezgrzeszność, to widzi w tym fakcie nie mechaniczne uwolnienie od grzeszności, ale Jej wielkość i owoc współpracy z Bogiem (por. BMB, s. 130). Wydaje się, że właściwie odczytana treść dogmatu pozwala na sformułowanie wniosku, że nie chodzi o predestynację do świętości, ale o uzdolnienie do współpracy Maryi z Bogiem obdarzającym Ją łaską. Nie należy widzieć w tym mechanizmu (byłby to „monofizytyzm” zbawczy), ani nie wolno rozdzielać łaski Bożej i wolnej woli Maryi („nestorianizm”), należy zachować i jedno, i drugie. 
wyjątkowe, ale przecież daje się w nim wyczytać regułę obowiązującą wszystkich: uprzednia łaska Boża umożliwia człowiekowi otwarcie się na dar łaski Odkupienia. Jeśli grzesznik miał zostać uleczony, proces zdrowienia musiał objąć uzdrowienie jego woli, która sprawiła śmiertelną chorobę. Bóg wzywa do pełnienia Jego woli swoją łaską, która nie zniewala wolnej woli, owszem właśnie dzięki jej zbawieniu umożliwia nam posłuszeństwo Bogu. Już jesteśmy zbawieni z łaski, po to, by współpracować w łasce zbawienia i móc być zbawionymi. Sprawia to wrażenie „błędnego koła”, ale właśnie ten paradoks jest wyrazem prawdy o Bogu i człowieku oraz dobrze odpowiada logice zbawczej: Bóg wymaga współpracy człowieka, ta zaś nie jest możliwa bez uprzedniego wybawienia grzesznika od tej niezdolności; w mocy łaski staje się on zdolny do odpowiedzi na wezwanie samego Boga! W takim razie Niepokalane Poczęcie jest podkreśleniem zarówno „niezgłębionych wymiarów życia wewnętrznego”, jak i „nieograniczonej wspaniałości łaski Bożej”, a także „zła grzechu, darmowości odkupienia i świętości Boga"79.

\section{Uprzednie Odkupienie realizuje się w czasie}

Historyczne pośrednictwo Maryi w wejściu Boga w ludzkie dzieje ma oczywiście, jak zauważa kierownik Katedry Teologii Historycznej na KUL-u, ks. prof. Mirosław Kowalczyk, ,swoje odniesienie do pośrednictwa pozahistorycznego, czyli zbawczego, gdyż tam osiąga swój sens i cel"; jeśli Bogorodzicielstwo realizuje się w doczesności, to „przecież konsekwencje tego prapośrednictwa w rodzicielstwie przenoszą się poza świat stworzony i historyczny". Bez fiat Nowej Ewy panowałby stary porządek naznaczony nieposłuszeństwem pierwszej Ewy, z kolei zgoda Matki Bożej „odwraca ten porządek w przestrzeni historycznej, co ma jednocześnie znaczenie dla duchowej przestrzeni pozahistorycznej, czyli zbawczej"80.

Jeśli od zgody Matki zależało Jej i nasze Odkupienie (w takim razie jest Ona Matką naszego Zbawienia), to jest to wyjątek od reguły, którą można sformułować następująco: również od nas zależy do pewnego stopnia zbawienie innych, z kolei na pewno mamy udział w swoim odkupieniu. Jak Matka, tak i Jej duchowi synowie, mają udział w swoim odkupieniu, ,zanim” ono się dokona w historii, choć w wieczności już zostało przewidziane. W pewnym więc sensie wszyscy zostaliśmy jak

\footnotetext{
$79 \quad$ BMB, s. 135.
}

80 M. Kowalczyk, Posłowie. Maryja Matka historii odnowionej w Chrystusie, [w:] BMB, s. 320. 
Matka uprzednio odkupieni; nie jesteśmy niepokalani, ale również nasze Zbawienie dokonuje się na wzór Odkupienia Niepokalanie Poczętej, choć z drugiej strony - różni się od niego, bo stan Niepokalanie Poczętej nie jest tym samym, co stan osoby po chrzcie świętym ${ }^{81}$.

Bóg przewiduje nasze czasowe fiat, i je uwzględnia w odwiecznym Mariologia planie. Ostatecznym tego wszystkiego wyrazem jest współpraca Maryi z Bogiem w dziele Zbawienia. Nowa Ewa okazuje się konieczną pomocą dla Nowego Adama (por. Rdz 2,18), by Zbawienie mogło się zrealizować; również potomstwo Niewiasty nie pozostaje bierne, ale bierze aktywny udział w walce z szatanem (por. Rdz 3,15 ).

\section{Spotkanie doczesności z wiecznością}

Gdyby nie odwieczna wola Boża, w której jesteśmy odkupieni, nie przyszedłby Odkupiciel. Ale i odwrotnie: gdyby Bóg nie stał się człowiekiem „dla naszego zbawienia”, jak wyznajemy w Credo, gdyby nie dokonał naszego odkupienia w czasie, nie byłby możliwy odwieczny Boży plan Zbawienia człowieka. Tylko w Tym, który żyje zarówno w czasie, jak i w wieczności (Bóg i człowiek), jest możliwe wzajemne spotkanie i oddziaływanie wieczności i czasu. Dopiero pojęcie tego prowadzi do zrozumienia, że od naszego życia na ziemi zależy nasza wieczność - nie w sensie wiecznej niebiańskiej nagrody za przeżyty tak a nie inaczej czas na ziemi, ale mocą faktu, że jako chrześcijanie jesteśmy tu, ale w Chrystusie już tam ${ }^{82}$.

Słowa kluczowe: Bóg, człowiek, Chrystus, Wcielenie, Maryja, Matka Boża, Niepokalane Poczęcie, wola, czas, wieczność, historia, predestynacja, wolność, łaska, współpraca, Odkupienie, powołanie.

\section{Bibliografia:}

1. Bartnik Cz., Matka Boża, Lublin 2012.

2. Benedykt XVI, Audiencja generalna w Wielka Środę: ,Tajemnica Wielkiego Tygodnia umacnia wiare”" (20.04.2011), L'OssRom (PL) (2011) nr 6.

3. Benedykt XVI, Audiencja generalna: , «Tak» powiedziane Bogu szczytem wolności”(01.02.2012), L'OssRom (PL) (2012) nr 4.

$81 \quad$ Por. BMB, s. 133.

82 Artykuł niniejszy w skróconej wersji został przedstawiony 8.XII.2014 r. w Archidiecezjalnym Wyższym Seminarium Duchownym w Białymstoku w ramach Akademii z okazji uroczystości Niepokalanego Poczęcia Najświętszej Maryi Panny. 
4. Bulla papieża Piusa IX,,Ineffabilis Deus”, 8 grudnia 1854 r., [w:] I. Bokwa (red.), Breviarium fidei. Wybór doktrynalnych wypowiedzi Kościoła, oprac. I. Bokwa [i in.], Poznań 2007.

5. Bulla papieża Piusa IX „Ineffabilis Deus”.

6. Chodkowski F. K., „Ty jesteś Chrystus Syn Boga żywego”. Zarys chrystologii Josepha Ratzingera, Poznań 2007.

7. Dokumenty Soborów Powszechnych. Tekst grecki, łaciński, polski. Tom I, Nicea I, Konstantynopol I, Efez, Chalcedon, Konstantynopol II, Konstantynopol III, Nicea II (325-787), układ i oprac. A. Baron, H. Pietras, Kraków 2007.

8. Ernst M., Tajemnica, tłum. T. Siemieniec, [w:] F. Kogler, R. Egger-Wenzel, M. Ernst (red.), Nowy leksykon biblijny, red. nacz. nauk. wyd. pol. H. Witczyk, Kielce 2011.

9. Franciszek, encyklika Lumen fidei (O wierze), Wrocław 2013.

10. Guitton J., Maryja, tłum. T. Dmochowska, Warszawa 1956.

11. Gumbel N., Co nas nurtuje. Siedem powszechnie wysuwanych zastrzeżen pod adresem chrześcijaństwa, tłum. R. Pruszkowski, Warszawa 1998.

12. Jan Paweł II, encyklika Redemptoris Mater.

13. Kobelski P. J., List do Efezjan, [w:] R. E. Brown, J. A. Fitzmyer, R. E. Murphy (red.),Katolicki komentarz biblijny, red. wyd. pol. W. Chrostowski, red. nauk. W. Chrostowski, tłum. K. Bardski [i in.], Warszawa 2004.

14. Kolbe M. M., Pisma. Cz. II, przyg. do druku P. Sotowski, Niepokalanów 2008.

15. Komentarz żydowski do Nowego Testamentu, tłum. Nowego Testamentu i kom. D. H. Stern, tłum. A. Czwojdrak, Warszawa 2004.

16. Kowalczyk M., Postowie. Maryja Matka historii odnowionej w Chrystusie, [w:] Bartnik Cz., Matka Boża, Lublin 2012.

17. Lipniak J.M., Pierwsza wśród usprawiedliwionych. Reinterpretacja dogmatu o Najświętszej Maryi Panny w świetle ,Wspólnej deklaracji w sprawie nauki o usprawiedliwieniu", Wrocław 2012.

18. Luter M., Komentarz do „Magnificat” (1521), [w:] Teksty o Matce Bożej. Chrześcijaństwo ewangelickie, tłum. E. Adamiak i in., Niepokalanów 2000, s. 135 .

19. MacDonald M. Y., List do Efezjan, tłum. T. Mieszkowski, [w:] W. R. Farmer (red.), Międzynarodowy komentarz do Pisma Świętego. Komentarz katolicki i ekumeniczny na XXI wiek, red. wyd. pol. W. Chrostowski, tłum. H. Bednarek [i in.], Warszawa 2001.

20. Napiórkowski S .C., Spór o Matkę Pana. Mariologia jako problem ekumeniczny, Lublin 2011.

21. Newman J. H., Odnajdywanie Matki. List do wielebnego Bouverie Puseya doktora teologii dotyczacy jego ostatniego Eireniconu, tłum. W. Życiński, Niepokalanów 1986.

22. Paweł VI, adhortacja apostolska Signum magnum (O czci i naśladowaniu Najświętszej Panny Maryi, Matki Kościoła i wzoru wszystkich cnót), www. opoka.org.pl.

23. Rahner K., Pisma wybrane, t. 2, wyb. tekstów i tłum. G. Bubel, Kraków 2007. 
24. Ratzinger J. (Benedykt XVI), Jezus $z$ Nazaretu, cz. 2: Od wjazdu do Jerozolimy do Zmartwychwstania, tłum. W. Szymona, Kielce 2011.

25. Ratzinger J. (Benedykt XVI), Jezus z Nazaretu. Dzieciństwo, tłum. W. Szymona, Kraków 2012.

26. Ratzinger J. (Benedykt XVI), Urs von Balthasar H., Maryja w tajemnicy Kościoła, tłum. W. Szymona, Kraków 2007.

27. Ratzinger J. (Benedykt XVI), Wzniosła Córa Syjonu, tłum. J. Królikowski, Poznań 2002.

28. Ratzinger J., Chrystus i Jego Kościót, tłum. W. Szymona, Kraków 2005.

29. Ratzinger J., O sensie bycia chrześcijaninem, tłum. J. Merecki, Kraków 2006.

30. Ratzinger J., Patrzeć na przebitego. Szkice o chrystologii duchowej, tłum. J. Merecki, Kraków 2008.

31. Ratzinger J., Seewald P., Bóg i świat. Wiara i życie $w$ dzisiejszych czasach. $Z$ kardynatem Josephem Ratzingerem Benedyktem XVI rozmawia Peter Seewald, tłum. G. Sowinski, Kraków 2005.

32. Ratzinger J., Świętego Bonawentury teologia historii, tłum. E. I. Zieliński, Lublin 2010.

33. Ratzinger J., Wprowadzenie w chrześcijaństwo, tłum. Z. Włodkowa, Kraków 2012.

34. Scheffczyk L., Maryja. Matka i Towarzyszka Chrystusa. Podręcznik mariologii, tłum. J. Tumielewicz, Kraków 2004.

35. Schönborn Ch., Ikona Chrystusa, tłum. W. Szymona, Poznań 2001.

36. Schönborn Ch., Przebóstwienie, życie i śmierć, tłum. W. Szymona, Poznań 2001.

37. Sobór Konstantynopolitański (680-681). Wyktad wiary, nr 14.16 i 19, [w:] Dokumenty Soborów Powszechnych. Tekst grecki, łaciński, polski. Tom I, Nicea I, Konstantynopol I, Efez, Chalcedon, Konstantynopol II, Konstantynopol III, Nicea II (325-787), układ i oprac. A. Baron, H. Pietras, Kraków 2007.

38. Sobór Watykański II, Konstytucja dogmatyczna o Kościele „Lumen gentium".

39. Sobór Watykański II, Konstytucje, dekrety, deklaracje. Tekst polski. Nowe ttumaczenie, Poznań 2002.

40. Wybrane zagadnienia chrystologii (1979), tłum. J. Bielecki, [w:] J. Królikowski (red.), Od wiary do teologii. Dokumenty Międzynarodowej Komisji Teologicznej 1969-1996, Kraków 2000.

41. Wyznanie wiary Soboru Chalcedońskiego, 451 r., [w:] Breviarium fidei. Wybór doktrynalnych wypowiedzi Kościoła, oprac. S. Głowa, I. Bieda, Poznań 1998.

42. Zatwardnicki S., Ateizm urojony. Chrześcijańska odpowiedź na negacje Boga, Kraków 2013.

43. Zatwardnicki S., Hermeneutyka wiary $w$ nauczaniu papieża Benedykta XVI.

44. Zatwardnicki S., Pomoc przeciw nieprzyjaciołom Twoim, czyli jak chwalić Maryję i bronić Jej godności, Kraków 2014.

45. Życiński W., Mariologia Kościoła anglikańskiego, [w:] Teksty o Matce Bożej. Chrześcijaństwo ewangelickie, tłum. E. Adamiak i in., Niepokalanów 2000. 